PIOTR GUZOWSKI (Białystok)

\title{
POSTAWA PRYMASA BERNARDA MACIEJOWSKIEGO W DOBIE ROKOSZU SANDOMIERSKIEGO
}

Stanisław Albrecht Radziwiłł, uczestnik i obserwator życia politycznego w Rzeczypospolitej, po latach w swoim Rysie panowania Zygmunta IIInapisał: „Baldachim, pałac i starostwo dudeńskie [...] rokoszu było przyczyną." ${ }^{1}$ W podobnym duchu o genezie nękającego kraj konfliktu wewnętrznego wypowiadał się inny komentator spraw publicznych, Paweł Piasecki, dodając, że to „Wesele królewskie dało powód do wewnętrznych niezgód [...]” "2. Rzeczywiście w trakcie uroczystości weselnych Zygmunta III Wazy i arcyksiężniczki Konstancji w grudniu 1605 r. doszło do dwóch słynnych incydentów poróżniających króla $\mathrm{z}$ wojewodą krakowskim Mikołajem Zebrzydowskim i kardynałem Bernardem Maciejowskim, których symbolami stały się właśnie pałac i baldachim. Po pierwsze bowiem z domu przylegającego do siedziby królewskiej, tradycyjnie zajmowanego przez zarządców zamku, eksmitowano ludzi Mikołaja Zebrzydowskiego, starosty zamku, robiąc tym samym miejsce innym weselnikom. Po drugie na oczach kardynała Bernarda Maciejowskiego rozebrano prestiżowy baldachim nad jego tronem w kościele, przysługujący mu jako legatowi papieskiemu na ślub ${ }^{3}$. Mikołaj Zebrzydowski od dawna był w opozycji wobec rządów Zygmunta III. Konflikt o pałac, dotykający wojewodę bezpośrednio, pogłębił tylko już istniejącą wzajemną niechęć, natomiast spór o baldachim został odczytany jako gwałtowne zerwanie kardynała $z$ monarchą i dołączenie do wielkiego już i tak grona krytyków rządów w Rzeczypospolitej.

1 St. A. Radziwiłł, Rys panowania Zygmunta III, „Atheneum” 1848, t. III, s. 28.

2 Kronika Pawta Piaseckiego, Kraków 1970, s. 193.

3 Ibidem. 
Wypadki te, raczej przecenione przez współczesnych, wpisały się jednak znacząco w scenariusz wydarzeń politycznych zapowiadających rokosz sandomierski. Złożona sytuacja polityczna wewnątrz Rzeczypospolitej, w której żadna klasa polityczna: ani szlachta, ani magnateria, ani wreszcie król, nie była zadowolona $z$ istniejącego stanu rzeczy, powodowała napięcie społeczne grożące wybuchem konfliktu. Ustrój demokracji szlacheckiej dryfujący w stronę oligarchii magnackiej nie był w stanie zapewnić bezpieczeństwa państwu od zagrożeń zewnętrznych i nie próbował walczyć z brakiem porządku w kraju. W obliczu widocznego kryzysu parlamentu, kiedy „[...] w przeciągu czternastolecia 1592-1606 pięć sejmów spełzło na niczym, a inne nie były w stanie rozstrzygnąć żadnej z ważniejszych nurtujących państwo i społeczeństwo spraw" 4, król oparł swoje rządy na elicie magnackiej. Opozycyjnie nastawiony do władzy kanclerz Jan Zamoyski nie współpracował z Zygmuntem III i wykorzystując sławę swojego imienia, potęgę urzędów oraz majątku, stał się filarem opozycji, która nie potrafiła wybaczyć królowi jego nie do końca zrozumiałych i wyjaśnionych związków z Habsburgami. Sytuację Rzeczypospolitej komplikowało także to, że jej władca chciał skutecznie zarządzać dwoma swoimi królestwami, a gdy jedno z nich stracił, nie pogodził się z myślą o ostatecznej rezygnacji z roszczeń do zamorskiej ojczyzny. Szwedzkie zagrożenie wojną w Inflantach skutecznie oczyszczało skarb z i tak skromnych dochodów, których wzrostu szlachta nie chciała. Wszelkie królewskie próby scentralizowania rządów i reformy ustroju zbijane były demagogicznym argumentem szlacheckim o rodzącym się absolutum dominium, stąd król zbudowawszy krąg mniej lub bardziej zaufanych senatorów, w oparciu o radę próbował na bieżąco rozwiązywać aktualne problemy.

Wśród najbliższych współpracowników władcy najważniejsze miejsce zajmowali marszałek wielki koronny Zygmunt Myszkowski, podkanclerzy koronny, a następnie kanclerz Maciej Pstrokoński, wojewoda poznański Hieronim Gostomski. Duży wpływ na poglądy królewskie mieli także młodsi politycy, jak Feliks Kryski, biskup łucki Marcin Szyszkowski czy Andrzej Bobola ${ }^{5}$.

$\mathrm{Na}$ swoje miejsce w stronnictwie królewskim zapracował też Bernard Maciejowski. Biskupem łuckim mianowany został jeszcze przez Annę Jagiellonkę w czasie bezkrólewia w 1587 r., a nowy władca nominację tę później zatwierdził. W tym czasie $\mathrm{z}$ powodzeniem posłował w imieniu Zygmunta III

4 J. Maciszewski, Wojna domowa w Polsce (1606-1609), cz. 1, Wrocław 1960, s. 73.

5 St. Cynarski, Stronnictwo królewskie $w$ dobie rokoszu Zebrzydowskiego, „Małopolskie Studia Historyczne" R. 8, 1965, z. 3, s. 3-9. 
do Rzymu, a po powrocie zajął się realizacją reform trydenckich w swojej diecezji. Aktywny udział w tworzeniu unii brzeskiej zaowocował ponowieniem przez Zygmunta III Wazę próby przesunięcia Bernarda Maciejowskiego na biskupstwo wileńskie. Po niepowodzeniu tej akcji król mianował go biskupem krakowskim, uhonorowanym dodatkowo przez papieża kapeluszem kardynalskim w 1604 r. za zaangażowanie w działalność duszpasterską. 16 IV 1605 r. Zygmunt III Waza nominował Bernarda Maciejowskiego na arcybiskupstwo gnieźnieńskie ${ }^{6}$.

Kardynał nie angażował się bezpośrednio w politykę, dzięki czemu traktowano go jako człowieka dworu, ale jednocześnie utrzymywał też dobre stosunki z liderem opozycji w kraju (po śmierci Jana Zamoyskiego), Mikołajem Zebrzydowskim. Łączyła ich wspólna służba na dworze Stefana Batorego oraz pomysł ufundowania kolegium jezuickiego w Lublinie, realizowany przy pomocy Piotra Skargi od 1580 r. ${ }^{7}$ Później Bernard Maciejowski już jako biskup krakowski zaangażował się w tworzenie przez wojewodę krakowskiego fundacji w Kalwarii Zebrzydowskiej ${ }^{8}$.

Próbą wytrzymałości przyjaźni kardynała była sprawa drugiego małżeństwa królewskiego. Mikołaj Zebrzydowski ostro protestował przeciw kandydaturze Konstancji, siostry zmarłej pierwszej żony króla. Swoją dezaprobatę wyrażali również przedstawiciele duchowieństwa. Mimo iż planowane małżeństwo nie było zgodne $\mathrm{z}$ prawem kanonicznym, to po dyspensie papieskiej, na wyraźne żądanie króla, Bernard Maciejowski pracował nad przeforsowaniem tego pomysłu wśród senatorów ${ }^{9}$. Robił to dosyć skutecznie, a $\mathrm{z}$ czasem został nawet legatem papieskim na tenże ślub, ale sprawiał wrażenie człowieka $z$ niechęconego do postawy władcy ${ }^{10}$. Incydent $z$ baldachimem wywarł wrażenie na aktorach sceny politycznej w Polsce i miał prawo być odczytany jako zapowiedź akcesu zwierzchnika Kościoła do opozycji.

Kiedy Zygmunt III Waza zwoływał sejmiki przedsejmowe na początku 1606 r., nie przypuszczano, że dadzą one początek wojnie domowej w kraju. Kardynał Bernard Maciejowski w liście do Lwa Sapiehy pisał: „Jam teraz

6 P. Guzowski, Działalność polityczna Bernarda Maciejowskiego. Praca magisterska napisana pod kierunkiem prof. dr. hab. A. Wyczańskiego, Białystok 1999; J. Dzięgielewski, J. Maciszewski, Bernard Maciejowski, w: Polski Stownik Biograficzny, Wrocław-Warszawa-Kraków-Gdańsk 1974, t. XIX, s. 48-51.

7 Listy Piotra Skargi TJ z lat 1566-1586, wyd. J. Sygański, Kraków 1912, s. 135-137.

8 Biblioteka Zakładu im. Ossolińskich we Wrocławiu, rkps 91, k. 150-151.

9 St. Łubieński, Pisma pośmiertne, przeł. A. B. Jocher, Petersburg-Mohylew 1855, s. 50 .

10 W. Sobieski, Pamiętny sejm, Kraków 1913, s. 13. 
żałośny, że wedle powinności i zwyczaju mego, nie mogę być na sejmiku Prossowskim, łatając zdrowie gwałtem bólu do tego przyciśniony. Mam jednak nadzieję, że tam nic nie będzie, coby Rzplitą trudnić miało." 11 Tymczasem plany królewskie zaprezentowane na sejmikach wywołały lawinę powszechnej krytyki. Usprawnienie obrad sejmu poprzez ograniczenie dyskusji parlamentarnych tylko do spraw poruszonych w propozycji królewskiej, zabezpieczenie obrad przed ich zerwaniem czy złożeniem protestacji, ustanowienie stałych podatków oraz wprowadzenie stałej armii zostały odczy tane jako zagrożenie wolności szlacheckich. Mikołaj Zebrzydowski na sejmiku województwa krakowskiego w Proszowicach zaproponował by szlachta w czasie sejmu urządziła zjazd, który broniłby republiki przed zamachem króla. Pomysł wojewody krakowskiego podchwycono w wielu regionach kraju i na dziesięć dni przed końcem nadchodzącego sejmu (9 VIII 1606 r.) miał się odbyć zjazd w Stężycy, miasteczku należącym do starostwa Mikołaja Zebrzydowskiego ${ }^{12}$. Ani kardynał i prawdopodobnie nikt ze stronnictwa królewskiego nie przewidział, że arcykatolicki Zebrzydowski porozumie się z przywódcami protestantów, Januszem i Krzysztofem Radziwiłłami, i nawiązując do legendy Jana Zamoyskiego, będzie próbował zająć jego miejsce na scenie politycznej.

Na sejm 1606 r. nie przybył wojewoda krakowski, a arcybiskup - nominat spóźnił się. Z tego powodu uważano, iż senat został zdominowany przez regalistów, natomiast izba niższa parlamentu, podbudowana obecnością księcia Janusza Radziwiłła sprzeciwiała się propozycjom królewskim. W gorącej atmosferze sformułowano pod adresem władcy listę „uraz”, a następnie skrytykowano „respons królewski”, po czym wysunięto zarzuty także przeciw duchowieństwu katolickiemu, żądając uchwalenia „procesu” konfederacji warszawskiej. Zygmunt III wraz $\mathrm{z}$ senatorami regalistycznymi postanowił ofiarować opozycji konstytucję o tumultach w zamian za jej zgodę na podstawowe reformy w kraju. Takiemu stanowisku sprzeciwili się ustami Bernarda Maciejowskiego senatorowie duchowni i sejm nie przyjął żadnej konstytucji, tylko uchwałę o poborze, popartą przez niewielu posłów, przez większość pozostawioną do rozstrzygnięcia sejmikom relacyjnym ${ }^{13}$. Część posłów opozycyjnych po zakończeniu obrad sejmowych wyjechała do Stężycy, gdzie postanowiono zwołać na 4 VI 1606 r. kolejny zjazd, tym razem pod Lublinem.

11 Archiwum domu Sapiehów, opr. Antoni Prochaska, Lwów 1892, t. 1, nr 592, s. $482-483$.

12 W. Sobieski, op. cit., s. 46-51.

13 Ibidem, s. 179, 216-217. 
Zaniepokojony powagą sytuacji w Koronie kanclerz litewski, Lew Sapieha pisał 9 V 1606 r. do kardynała Maciejowskiego: „Wszytka nadzieja zachwianej barzo ojczyzny zostawa na samem staraniu i obmyśliwaniu Wmci m.m. pana, na którem, wiem, że jej nie schodzi i schodzić nie będzie. WMć jako primus princeps et praesul masz ją dźwigać i ratować w tak złym razie." Liczył bardzo na dobre prywatne kontakty arcybiskupa $z$ wojewoda krakowskim, w przeciwnym bowiem razie „[...] czego Boże uchowaj, by do tego przyjść miało, alias co inszego jeno civile bellum wprowadzą" ${ }^{14}$.

Kiedy na początku maja 1606 r. Mikołaj Zebrzydowski wjechał w triumfalnym pochodzie do Krakowa, kardynał rozpoczął starania zmierzające do zażegnania konfliktu. Nie przyniosły one jednak większych rezultatów, o czym poinformował Lwa Sapiehę: „[...] nie opuściłem i jednej godziny starać się o to, com rozumiał być potrzebnego do pogładzenia i uspokojenia tych zaciągnionych rzeczy. Jednak tak prędko ostatecznej rezolucyjej wziąć trudno." 15 Wojewoda krakowski szykował się na zjazd lubelski i jedyne co na razie można było zrobić, to: „[...] aby JKr. Mć na ten tam zjazd lubelski ludzie cum autoritate et predentia posłał, którzyby upewnieniem od $\mathrm{KKr}$. Mci bezpiecznie z ludźmi mówić i asekurować ich mogli" ${ }^{16}$. W międzyczasie zaś arcybiskup zdołał wysondować stanowisko kasztelana krakowskiego Janusza Ostrogskiego, wahającego się między otwartym akcesem do opozycji a przystąpieniem do obozu królewskiego w zamian za np. wakującą buławę hetmana wielkiego koronnego ${ }^{17}$.

Większość sejmików posejmowych 1606 r. zamiast uchwalać pobór, na czym szczególnie zależało Zygmuntowi III, zajęła się wyborem delegacji na zjazd lubelski. Najbardziej gwałtowny przebieg miał sejmik województwa poznańskiego i kaliskiego, gdzie wielka liczba szlachty podzieliła się na dwa koła: regalistów i opozycji. Obie grupy powzięły odrębne uchwały, których cechą wspólną był wniosek o zmobilizowanie arcybiskupa - nominanta do pracy nad przywracaniem pokoju wewnętrznego. Regaliści w swym uniwersale pisali: „Do JM zasię ks. Kardynała wszakże za wiadomością i oznajmeniem tego JKM, aby jako przedniejszy senator także i duchowny, pospołu $\mathrm{z}$ drugimi ichmciami pany senatoram duchownemi $\mathrm{w}$ to się interponował,

14 Archiwum..., nr 602, s. 492-493.

15 Ibidem, nr 606, s.495.

16 Ibidem.

17 Ibidem, nr 601, s. 492; V. Urbaniak, Zamoyszczycy bez Zamoyskiego. Studium dekompozycji ugrupowania politycznego, Warszawa 1995, s. 65, 67. 
aby ichm. mogli mieć wiadomość zamysłów, przed się wzięcia jm p. wojewody krakowskiego i taki w tym postępek uczynić raczeli, jakiego rzecz sama potrzebowała, nas o wszystkim wiadomemi czyniąc." $18 \mathrm{~W}$ podobnym duchu przemawiał do Bernarda Maciejowskiego poseł opozycjonistów - secesjonistów sejmiku średzkiego, sugerując, że: ,[...] powinien w takowej chorobie R.P. poczuwać się i onę pilnym a mądrym i skutecznym staraniem leczyć." ${ }^{19}$ Kardynał był postrzegany jako osoba mogąca spełnić rolę mediatora, bez wątpienia liczono na jego przyjaźń zarówno z Mikołajem Zebrzydowskim, jak i z królem, ufano prestiżowi urzędu prymasowskiego, choć w wystąpieniach sejmikowych pojawia się także nuta zniecierpliwienia.

Zjazd lubelski (4-17 VI 1606 r.) swoim radykalizmem zraził do siebie część obecnych na nim senatorów, co przesunęło ich bliżej tronu (np. Stanisław Żółkiewski), reszta zaś (Mikołaj Zebrzydowski, Janusz Radziwiłł czy Stanisław Stadnicki) pogrążyła się w idei przewodzenia masom szlacheckim. Postanowiono zwołać na 6 VIII rokosz i wezwano króla oraz prymasa do zgromadzenia wszystkich senatorów tegoż dzień w Sandomierzu. Ponadto uchwalono zbiórkę pieniędzy na wojsko, a sytuację w kraju określano mianem bezkrólewia.

Zygmunt III Waza w odpowiedzi na groźbę rokoszu wezwał do Krakowa wszystkich senatorów na konwokację i odmówił stawienia się w Sandomierzu. Tu do wiadomości prymasa, a przez niego też i do samego króla, dotarła wiadomość o wydaniu przez papieża Pawła V specjalnego brewe ekskomunikującego Wenecję, znajdującą się w konflikcie ze Stolicą Apostolską. Na prośbę władcy prymas Bernard Maciejowski zaniechał opublikowania tekstu decyzji papieskiej, Wenecję bowiem stawiała opozycyjna propaganda za wzór uniezależnienia się od wpływów papieskich i jezuickich ${ }^{20}$.

Zjazd szlachty rokoszowej w Pokrzywnicy pod Sandomierzem szybko wymknął się spod kontroli Mikołaja Zebrzydowskiego. Wrogo przy jęto posłów królewskich, tak jak i list kardynała Maciejowskiego. Prymas zapewniał o swojej miłości do ojczyzny i przywiązaniu do wolności, ale wzywał do stworzenia programu usprawnienia prawa, możliwego do wykonania i wprowadzenia w życie środkami pokojowymi. „Tegom pewien, że WM [...] tak te rzeczy stosujecie i namówicie poprawę praw i zatrzymanie wolności ze spólną

18 Akta sejmikowe województw poznańskiego i kaliskiego, wyd. Włodzimierz Dworzaczek, Poznań 1957, t. 1, cz. 1, s. 294.

19 Ibidem, s. 302.

20 J. Garbacik, Polska wobec konfliktu Wenecji z papieżem Pawtem V, „Collectanea Theologica", R. 19, 1938, s. 167. 
pociechą, ochroną całości i bezpieczeństwa Rzeczypospolitej." Gwarantował przy tym, że zrobi wszystko dla ustabilizowania sytuacji w kraju: „Z czym i pod zaciągiem tego zjazdu do uspokojenia dalszych zaciągów, wieloż osobom opowiedałem się, jakoż mając za cel wszystkich sprawy dobre i spokojne Rzeczypospolitej obronę praw i wolności." ${ }^{21}$ Prymas nie wydał się jednak rokoszanom zbyt wiarygodny. Swój list pisał z Wiślicy, gdzie w tym czasie konstytuowała się konfederacja szlachty i magnaterii przy królu. Dlatego marszałek zjazdu stężyckiego podziękował w imieniu wszystkich za pismo kardynała, dodając krytycznie, że prymas powinien pokazać swoim działaniem a nie tylko listami, że się „,...] kocha w prawach i wolnościach" 22 . Opozycyjna szlachta odrzuciła także artykuły wiślickie oraz antyabsolutystyczne gwarancje królewskie, na straży których miała stać rada. Również potwierdzenie przez monarchę konstytucji o tumultach z 1593 r. oraz zagwarantowanie prawosławnym swobodnego odbywania praktyk religijnych nie spotkało się $\mathrm{z}$ uznaniem innowierców znajdujących się wśród rokoszan. Z drugiej strony Zygmunt III Waza odrzucił postulaty rokoszowe i po zarzuceniu pomysłu mediacji między stronami przez Janusza Ostrogskiego, wydawało się, że jedynym rozwiązaniem konfliktu będzie zbrojne starcie.

W tych okolicznościach szczególną solidarność z królem wyrazili duchowni katoliccy. Fakt odgrywania przez protestantów znaczącej roli w rokoszu oraz postulaty politycznego i majątkowego ograniczenia roli Kościoła katolickiego w Polsce przyczyniły się do utożsamienia przez biskupów interesów Kościoła z interesami króla. 17 IX 1606 r. w Busku, w kwaterze prymasa Bernarda Maciejowskiego, odbyła się narada najwyższych hierarchów, na której postanowiono wspomóc finansowo władcę Rzeczypospolitej. W liście do nieobecnego w Wiślicy biskupa warmińskiego Szymona Rudnickiego kardynał pisał: „Postanowiliśmy tedy spólnie w znacznej gromadzie Ich Mci X. Biskupów na ten czas do Wiślice do JKrM. zgromadzonych, abyśmy wszyscy duchowni króla JMć znaczną częścią prowentów naszych rocznych teraźniejsze et pro hac vice tantum ratowali." ${ }^{23}$ Akcja zebrania środków, mająca pozostać w tajemnicy, powinna była zakończyć się do lata przyszłego roku. Nie liczono już na szybkie zakończenie konfliktu, a sytuacja wymagała zdecydowanego działania, bowiem „Nie tylko na majestat

21 Rokosz Zebrzydowskiego. Materiaty historyczne poprzedzone przedmowa i rozprawa pod tytułem Ḱonfederacja i rokosz $w$ dawnem prawie polskiem, wyd. A. Rembowski, Warszawa 1893 , s. 62.

22 Ibidem.

23 Biblioteka Kórnicka w Kórniku, rkps 290, s. 202-203. 
boży i chwałę jego rzucono się, na dostojeństwo KrJM Pana naszego ostro nastąpiono, ale nawet na zniesienie i zepsowanie praw i wolności kościelnych mocno usadzono się." 24

W pierwszych dniach października prymas piszący do Szymona Rudnickiego nie wiedział, że spór na linii król - opozycja wydawał się kończyć. Zygmunt III Waza wraz ze swoimi wojskami dogonił rokoszan na przeprawie przez Wisłę pod Janowcem i w wyniku obrad senatorów z obu stron, doszło do ugody, na mocy której wszystkie sporne kwestie miał rozwiązać sejm roku 1607. Sam Maciejowski na przełomie 1606 i 1607 r. postanowił raz jeszcze przekonać Zebrzydowskiego do pokojowego rozwiązania problemów nurtujących kraj i zaprosił wojewodę krakowskiego na spotkanie do Częstochowy ${ }^{25}$. Do spotkania prawdopodobnie jednak nie doszło. Kardynał jak i pośrednicy w pertraktacjach otrzymali odmowną odpowiedź od przywódcy rokoszan. Nie widział on możliwości pogodzenia się z głównym swoim antagonistą, marszałkiem Zygmuntem Myszkowskim, miał też za złe królowi, że zwleka ze zwołaniem obiecanego szlachcie sejmu ${ }^{26}$.

Niecierpliwość z tego ostatniego powodu wykazywała również szlachta. Już na obradach roków ziemskich pod koniec 1606 r. w całym kraju dał się odczuć ponowny wzrost napięcia. Szlachta zebrana w styczniu 1607 r. w Kaliszu postanowiła zwołać sejmik generalny całej Wielkopolski do Koła celem wywarcia nacisku na króla. Wysłano także list do prymasa Maciejowskiego, w którym żalono się, że nie można doczekać się „[...] od KJM ukontentowania nas w pogwałconych prawach i wolnościach naszych po zwróceniu się z rokoszu i po onej a poniewolnej transakcji janowieckiej" ${ }^{27}$.

Prymas, mimo iż nie deklarował się jako zwolennik opozycji, a wręcz przeciwnie często wspierał króla swoją obecnością, wciąż utrzymywał także autorytet w oczach rokoszan. Wydawał się im jedynym, który może zapewnić spokojny przebieg żądanego i oczekiwanego sejmu. Sejmik kolski w lutym 1607 r., nawiązując do plotek o zbrojnych przygotowaniach Zygmunta III Wazy do obrad parlamentu, zażądał od Bernarda Maciejowskiego wydania tzw. asekuracji według przedstawionych przez szlachtę punktów: „Wszakżesz jeśliż wm naszego m. pana dania naśladować mamy, prosiemy, abyś wm. Masz m. pan nas albo raczej wszystek rycerski stan pod panowaniem

24 Ibidem.

25 Pisma polityczne z czasów rokoszu Zebrzydowskiego, wyd. J. Czubek, Kraków 1918, t. II, s. 215 .

26 Biblioteka Czartoryskich (dalej: Czart.), rkps 337, k. 344-349.

27 Akta..., t. I, cz. 1, s. 323. 
J.K.M. będacy w tym upewnić i asekurować raczył. Naprzód, iż K.J.M. i ichm. Pp. Senatorowie namienieni na ten sejm żołnierza nijakiego i asystencyj przed tymi mieszaninami niezwykłych, ani same przez się, ani per subordnates personas zaciągać nie będą, ale pacate bez nich przyjadą i ten sejm odprawować będą. Druga, że K.J.M. żadnych posiłków postronnych przeciw stanowi naszemu nie zaciągał, nie zaciąga ani zaciągać będzie. Trzecie, że artykuły rokoszowe ab equestris ordine na sejmie poparte aprobuje, utwierdzi i do skutku przywiedzie. Czwarta, iż na tym sejmie żadnego niepokoju, trudności, niebezpieczeństwa nie trzeba się obawiać, tym wszystkim osobom, które się za te sprawy przeszłych czasów ujęły i onych jakimkolwiek sposobem popierali." 28

W responsie Prymas dokładnie odpowiedział na każdy $\mathrm{z}$ warunków stawianych przez szlachtę, wyliczając: co do punktu pierwszego, to starał się by ",...] nieprzyjaźni i zaciągi, które znaczne są między ludźmi przednimi koła naszego senatorskiego, zniesione i pomiarkowane były. Zaczym już wątpliwości żadnej nie dostawało spokojnego i bez asystencyj niezwykłych na sejm stawienia się ich.” Przy drugim punkcie zauważył: „Przypatrzywszy się przez te wszystkie lata panowania JKM, obaczycieśmy to snadnie mogli, że nigdy do żadnych gwałtownych śrzodków nie uciekał się, ani posiłków cudzoziemskich przeciw stanom koronnym nie zaciągał, [...] pod nie tuszę i przyczyny nie baczę, dla którejby pan, gdy stany koronne według zwyczaju na sejm spokojne, jako widzę jest, a dobrą i pożyteczną ojczyźnie intencję stawia się, do niezwykłych asystencyj i gromad uciekać by się miał." Co do artykułów sandomierskich: „Na to deklaracyja dawna JKM. Niektóre już artykuły zjazdem wiślickim postanowione, utwierdziwszy, zaszła że temu wszystkiemu, co jedno do poprawy i pomnożenia praw i wolności za zgodną namową stanów koronnych należeć będzie, dosyć czynić chce." Punkt czwarty zaś rozwinął: „Trzymam to łasce i dobrotliwości JKM, z którą tak często tych czasów oświadczał się, że dla dobrego R.P., dla uspokojenia całego Korony tej, dla pozyskania sobie całej miłości poddanych swych, że to wszystko w zapomnienie puścić będzie raczył. O co ja pilnie starać się nie zaniecham." ${ }^{29}$ Nie spodobało się szlachcie stanowisko Bernarda Maciejowskiego. „Niespokojni ludzie ci, nie przestając na tej odpowiedzi kardynała, i biorąc ją za powód dalszego postępowania swego, wydają uniwersały, w których miotają najsroższe na króla potwarze, naznaczając zjazd nowy na dzień 28 Marca 
w Jędrzejowie, na którym zamknąć ostatecznie zamierzali działania zjazdu rokoszańskiego." ${ }^{30}$ Mimo wszystko wciąż ufano prymasowi, puszczono, co prawda, mimo uszu jego wezwanie: „Nie dajcie WM pochopu do dalszego rozerwania jedności w ojczyźnie. Ochrońcie aby rozróżnieniem dalszym do nieopłakanego upadku nie przyszła” ${ }^{31}$, ale zaznaczono przy tym: „W wm nie wątpimy, że nas wm nie opuścisz, raczej upadającemu mciwem ratunkiem będziesz." 32

Zjazd jędrzejowski zebrał się ostatecznie 18 IV 1607 r. i postanowił przenieść się bliżej Warszawy, gdzie $7 \mathrm{~V}$ rozpoczął się sejm. Sejmiki przedsejmowe zajęły w większości stanowisko popierania zarówno artykułów wiślickich jak i sandomierskich i z takim poleceniem wysłały posłów do stolicy. Parlamentarzyści z województw poznańskiego i kaliskiego mieli dodatkowo w instrukcji zaznaczone, że jeżeli król nie spełni żądań szlacheckich „,[...] tedy JM ksiądz kardynał jako prymas nasz ma wszystkim województwom wielkopolskim zjazd złożyć w Kole sześć niedziel po sejmie, jeśli zgoda innych województw przystąpi, na którym o sobie i wolnościach naszych radzić by nam przyszło." ${ }^{33} \mathrm{Na}$ razie jednak wspólnie obradujące senat i izba poselska skupiły się na stworzeniu jednolitego zestawu z artykułów wiślickich i sandomierskich, a król zapewnił, że zatwierdzi wszystko co zostanie w trakcie obrad ustalone. $18 \mathrm{~V} 1607 \mathrm{r}$. Bernard Maciejowski w imieniu senatu, a marszałek izby poselskiej Szczęsny Kryski w imieniu posłów, zwrócili się do Mikołaja Zebrzydowskiego, prosząc, aby przybył do Warszawy i wyjaśnił co wie o niebezpieczeństwach grożących Rzeczypospolitej ${ }^{34}$. W podobnym duchu uniwersał wydał Zygmunt III Waza, wzywając wszystkich wiedzących o jakichkolwiek niebezpieczeństwach dla kraju, aby stawili się przed wyłonionym $\mathrm{z}$ izby poselskiej i senatu sądem i przedstawili swoje oskarżenia. W skład sądu wszedł m.in. prymas Maciejowski³5. Gdyby do 13 VI 1607 r. nikt nie złożył oskarżenia, wtedy wszyscy niepokojący Rzeczpospolitą będą mieli przeciw sobie króla i parlament. Uniwersał, jak i wcześniej wymienione listy, miały za zadanie ukrócić spekulacje wokół rewelacji o knowaniach monarszych, których ogłoszenie od roku zapowiadał Mikołaj Zebrzydowski. Ani jednak wojewoda krakowski, ani nikt inny nie zdecydował się na złożenie

St. Łubieński, op. cit., s. 32.

Akta..., t. I, cz. 1, s. 333.

32

33

Ibidem, s. 348 .

34

35

Ibidem, s. 373.

Czart., rkps 340, k. 542. 
zeznań przed sądem, stąd też parlament pracował w spokojnej atmosferze, a jedynie dyskusje wywoływały kontrowersje między szlachtą a duchowieństwem. Nie chodziło tu tylko o proces konfederacji warszawskiej, ale przede wszystkim o to, że w sprawach spornych między świeckimi a duchownymi, ci ostatni odwoływali się do Rzymu oraz o wysyłanie z Polski annatów. Duchowni zajęli negatywne stanowisko wobec żądań posłów, sugerując, że nie mogą podjąć wiążącej decyzji bez konsultacji z synodem prowincjonalnym. Prymas Bernard Maciejowski obiecał zwołanie tego synodu na 8 X 1607 r.

W liście do kapituły gnieźnieńskiej pisał: „Nietajne są WMM nawałności, które na then czas nastąpiły były na Kościół Boży, iakich trudności według możności i powinności bronią praw y wolności kościelnych na przeszłym seymie zażyliśmy, gdy iedne podnosić, drugie wielkim uciążeniem stanu naszego zwątlić chciano. Zaczem do tego przyszło, że w pewnych rzeczach na Synod Prowincjonalny odezwać ieśmy się musieli, z którego do umawiania pewnych punctów, które nas tak barzo z stanem świeckim, pewne osoby naznaczycieśmy przyobiecali." 36 Mieszana komisja mająca załatwić kwestie sporne między świeckimi a duchownymi miała decyzją sejmu rozpocząć swoje prace 11 XI 1607 r. w Warszawie ${ }^{37}$.

„W efekcie prac sejmu i postawy króla rokoszanie stanęli przed dylematem: uznać, że przedkładane żądania przynajmniej w zasadniczej części zostały spełnione, a zatem, że drogą właściwą, która prowadzi do naprawy państwa jest działanie poprzez sejm, albo zaprzeczyć rzeczom oczywistym. Wybrali to drugie." 38 Wezwali posłów przebywających w Warszawie do przerwania obrad i dołączenie do rokoszan. Takie stanowisko spotkało się z dezaprobatą sejmu i króla. Mimo to próbę rozmów z rokoszanami podjął Bernard Maciejowski. „Wśród szlachetnych pobudek tych i uczuć, za zgodą króla stanęło, aby pierwsi z senatu: kardynał Maciejowski, Piotr Tylicki biskup krakowski, Mikołaj Radziwiłł wojewoda wileński i inni udali się do rokoszan, dla skłonienia ich woli do woli ogółu. Udawszy się do obozu rokoszan, przedkładali oni usilnie wojewodzie krakowskiemu i Radziwiłłowi, aby bez zwłoki złożyli oręż i pojednali się z królem, do czego własne wdanie się i pomoc swoją zakładali." ${ }^{9}$ Prymas tak potem relacjonował spotkanie:

36 Cyt.za: J. Korytkowski, Arcybiskupi gnieźnieńscy, prymasowie, metropolici Polscy, Poznań 1889, t. III, s. 583.

37 Volumina legum, Petersburg 1859, t. II, s. 436.

38 H. Wisner, op. cit., s. 60.

39 St. Eubieński, op. cit., s. 142. 
"[...] pilnie dopytywaliśmy się o nich, aby co tak grątownego, żetelnego i słusznego podali, czymby Rzplita, i oni sami nie mieszając dalej Korony uspokoić się mogli. Lecz w zawziętych umysłach ani żądanie, ni staranie nasze tak uprzeyme miejsca nie miały, ani żadnego dictum responsu w tey mierze od nich odnieśćmy nie mogli." 40

Niepowodzenie tej, jak i kolejnych akcji prowadzonych przez wysłanników sejmu i króla spowodowały, że nie udało się zapobiec wypowiedzeniu przez rokoszan posłuszeństwa Zygmuntowi III. 24 VI 1607 r. w obozie pod Jeziorną akt podpisała szlachta, a zaaprobowało wojsko rokoszowe. W odpowiedzi król wydał uniwersały, ukazując obrazę dostojeństwa, monarchii, powagi sejmu i pokoju w kraju. W podobnym duchu wypowiedziała się specjalna deputacja sejmowa. Osobny uniwersał wydał arcybiskup gnieźnieński. Opisał w nim przebieg niepokojów w kraju oraz swoje, sejmu i króla starania zmierzające do zachowania pokoju wewnętrznego. Oświadczył też: „[...] że przy władzy, zwierzchności i dostojeństwie JKMci Pana mego oddając mu zwykłe i wierne Poddaństwo, przy Prawach i wolnościach, którym się gwałt za takim postępkiem dzieie, $\mathrm{z}$ drugimi Ichmościami cale stoię i opowiadam się.” Wzywał cały stan szlachecki królestwa, aby „Królowi Imci Panu swemu Pomazańcowi Bożemu, który nad nimi mocną rękę swą trzyma i niewinności tego surowym obrońca będzie, cole cnotę i wiarę powinnego poddaństwa oświadczli i dotrzymali i w domach swych aż do dalszego oznajmiania Jkmci i mego też, któremu to w takich czasiech należy, spokojnie a gotowi na wszelki gwałt do ratowania Pana i Oyczyzny będziecie oczekiwali." ${ }^{41}$ Kardynał nie miał już złudzeń, że nie dojdzie do zbrojnego starcia. Obie strony konfliktu zajęły stanowisko nieprzejednane, Bernard Maciejowski jako prymas stanął twardo przy królu, uniwersałem swym nie pozostawiając nikomu, co do tego wątpliwości. Gdy Zygmunt III wraz z wojskiem ruszał na rozprawę z rokoszanami „Kardynał Maciejowski zbliżywszy się na koniu do króla w mianej mowie składa mu życzenia na tę wyprawę, ale nie mniej zwraca jego myśli na to, iż walka ta ma być z synami jednej ziemi, jednej ojczyzny i zachęca go aby po odniesionym zwycięstwie przebaczyć wiarołomnym się nie wzbraniał. Na to Król łaskawie odpowiada: Żal i rozrzewnienie jest powszechne." 42

40 Czart., Teka Naruszewicza 103, k. 433.

41 Ibidem, s. 435.

42 St. Eubieński, op. cit., s. 147. 
5 VII 1607 r. doszło do bitwy pod Guzowem, w której wojska królewskie rozbiły rokoszan. Spośród dowódców wojsk rokoszowych pojmano tylko Szczęsnego Herburta, ale zbiegli inni przywódcy opozycji nie byli w stanie zorganizować dalszej obrony. Największą zawziętość wśród nich prezentował Janusz Radziwiłł, który mimo widocznej klęski ruchu, wydał uniwersał wzywający do elekcji nowego władcy 5 VIII 1607 r. w Warszawie. Nie spotkał się on $z$ odzewem od razu. Sejmiki relacyjne przebiegały bardzo spokojnie, wojewoda krakowski próbował pojednać się z królem, ale już w połowie października pod Warszawę zaczęły ściągać grupy niezadowolonych. Oprócz króla duże zaniepokojenie perspektywą nowego kryzysu wykazywało duchowieństwo zebrane $\mathrm{w}$ tym czasie na synodzie w Piotrkowie. 12 X 1607 r. biskupi wysłali do Warszwy list wzywający przybyłych na rokosz, aby „Skłonili się do tego, jakoby te zawzięcia i rozterki do których przyszło uśmierzone były i status tej rzeczypospolitej nadwątlonej był pokrzepion i naprawion." 43 Proponowali także użycie księdza prymasa jako mediatora $\mathrm{w}$ konflikcie $\mathrm{z}$ władcą. Kardynał będzie ,[...] takich szukał sposobów, albo, lekarstw, któreby ojczyznę naszą od tak szkodliwego razu wyswobodzić i wolną uczynic mogły. Do Ich M. tedy prosiemy abyście WM na ten nasz list odpisałi, a odpisali tak jakoby się ztąd pokazały umiarkowane waszmościów umysły i chęć do dobrego ojczyzny." 44

Propozycje biskupów przyjęto w Warszawie dosyć życzliwie. $17 \mathrm{X}$ 1607 r. przy jechał na zjazd Mikołaj Zebrzydowski i choć robił znaczne wyrzuty królowi, ostrzegł zgromadzonych przed nieszczęściem wojny domowej. Pewnie dlatego szlachta, początkowo dosyć agresywna, przystała na mediację duchowieństwa i $18 \mathrm{X}$ wysłała prymasowi swoje propozycje, a reprezentantem we wszelkich rokowaniach wyznaczyła wojewodę krakowskiego. Rokoszanie żądali: „Aby Imć Senat iak naypredzej na mieysce sposobne in centro Regi convocovać raczył, z którym żeby sposobów grątownego Rzplitej uspokoienia szukał [...] Tam co się naygrątownieyszego naydzie, aby to do skutku prędko i grątownie przyiwiedziono było[...] aby zaraz authoritatem suam interponeret iakboby [uwięzieni rokoszanie - dop. P.G.] byli bezdalszego zatrzymania wolni." Domagano się również odebranych przez Zygmunta III dzierżaw, majętności oraz zapewnienia opozycji bezpieczeństwa i odłożenia tzw. Kompozycji, czyli obrad komisji świecko-duchownej ${ }^{45}$.

43 Rokosz Zebrzydowskiego..., s. 131.

44 Ibidem, s. 133.

45 Czart., Teka Naruszewicza 103, k. 706. 
Odpowiedź prymasa skierowana do wojewody krakowskiego był uprzejma, acz stanowczo odmowna. Maciejowski nie dawał szans rokoszanom i wzywał do pozostania $\mathrm{w}$ wierności królowi. Jedyne wyjście $\mathrm{z}$ napiętej sytuacji w kraju widział w zwołaniu sejmu: „Lecz grątownego uspokoienia oyczyźnie życząc nie naydnię sposobu iedno żeby za znisieniem się stanów Koronnych na seymie." ${ }^{46}$ Co do bezpieczeństwa i wybaczenia win kardynał zauważył: „Doznawaliśmy przez te wszystkie czasy panowania Jkmci, że przychylniejszy zawsze był do pokazania łaski każdemu a niż surowości." 47 Kompromisowe wobec rokoszan postępowanie biskupów polskich oraz korespondencja Maciejowskiego spotkała się z ostrą reakcją hetmana Żółkiewskiego, zarzucającego duchownym, że swoimi inicjatywami bardziej komplikują sytuację polityczną niż zapewniaja pokój48. Prymas odrzucał te oskarżenia, wyjaśniał przyczyny akcji mediacyjnej i jej przebieg oraz dodał stanowczym tonem: „Widząc tedy dobre i szczere przeciw oyczyźnie i uspokoieniu iey intentie nasze, racz Wmć bez dalszych respectów kończyć zaczęte staranie swoje." 49

Odpowiedź kardynała rokoszanom, a także brak entuzjazmu Zebrzydowskiego i Radziwiłła dla zjazdów szlachty sprawiły, że ruch opozycji podupadł całkowicie. Jeszcze tylko na początku listopada 1607 r. kasztelan krakowski, Janusz Ostrogski, w liście do kardynała zagroził, że jeśli jako prymas nie zwoła senatu, to on jako pierwszy świecki senator wyda stosowny uniwersał ${ }^{50}$. Groźba ta, w obliczu kompletnego rozpadu rokoszu niewiele już znaczyła.

24 IV 1608 r. Zygmunt III Waza zwołał do Krakowa konwokację senatorską, mającą przygotować warunki przebaczenia win zbuntowanym przeciw władcy. 9 VI 1608 r. uniwersałem królewskim ogłoszono, że Zygmunt Waza przebaczy wszystkim, którzy go przeproszą i zapewnią o posłuszeństwie, a sejm 1609 r. potwierdził tą decyzję w konstytucji „Amnestia” 51.

Nie doczekał tych chwil prymas Polski, arcybiskup gnieźnieński, kardynał Bernard Maciejowski. Zmarł 19 I 1608 r. w Krakowie. Ostatnie dwa lata życia poświęcił doprowadzeniu do uspokojenia sytuacji w kraju. Oceniając skuteczność jego działań można wysunąć wiele wątpliwości: nie zapobiegł

46 Ibidem, nr 170, s. 702.

47 Ibidem, s. 703.

48 St. Łubieński, op. cit., s. 168.

49 Czart., Teka Naruszewicza 103, k. 706.

50 Ibidem, k. 709-710.

51 Volumina legum, t. II, s. 461-462. 
bowiem bitwie guzowskiej i przelewowi krwi. Wiele też można mu zarzucić cytu jąc pisarzy rokoszowych, podkreślających kumulowanie przez kardynała stanowisk biskupa krakowskiego i arcybiskupa gnieźnieńskiego oraz czerpanie podwójnych dochodów. Także historycy niezbyt wysoko cenili Bernarda Maciejowskiego. A. Strzelecki twierdził: „Wysoki ten dostojnik Kościoła nie odznaczał się wcale ani stałością zasad i charakteru, ani wielkimi zdolnościami, nie był ani tęgim politykiem, ani dyplomatą. Łatwo dawał się powodować okolicznościom, ale zawsze mimo tego się wahał, stąd trudno by go zaliczyć stale do jakiegoś z walczących obozów." 52 Podobną opinię wyraził W. Sobieski: „On tylko się ciągle waha, zajmuje stanowisko wyczeku jące i niejasne [...]. Ku opozycji pociąga go polski republikanizm, ale od rokoszu odpycha go znowu dominujący w nim żywioł innowierczy, atakujący duchowieństwo." 53

Analizu jąc działalność prymasa w trakcie rokoszu, należy jednak podkreślić jego stałość zasad i charakteru. Incydent $z$ baldachimem rysuje się jako wydarzenie zdecydowanie przeceniane przez potomnych, niewpływające w znaczący sposób na sytuację polityczną w kraju. Pozornie być może stosunki kardynała $\mathrm{z}$ monarchą ochłodziły się $\mathrm{w}$ związku z weselem królewskim, ale przecież nie przestał on być jednym z najwierniejszych przyjaciół Zygmunta III Wazy. Jak trafnie zauważyli autorzy biogramu Bernarda Maciejowskiego w Polskim Stowniku Biograficznym: „W odróżnieniu od innych czołowych biskupów pierwszego dziesięciolecia XVII w. nie należał do grona zwolenników absolutyzmu, w swej działalności usiłował oscylować między królem, w stosunku do którego był lojalny, a masami szlachty" ${ }^{54}$. Specyfika funkcji prymasa spowodowała, że nie mógł od razu wyraźnie opowiedzieć się po którejś ze stron konfliktu. Zdawał sobie sprawę, że po jednej, jak i drugiej stronie większość stanowią katolicy, których głową w tym kraju miał być właśnie on. Stąd jego poparcie dla monarchy nie było efektowne, ale inicjatywy zmierzające do przekonania Zebrzydowskiego o szkodliwości buntowania się, czy idea wsparcia finansowego króla miały swoje znaczenie. Wszelkie próby mediacji między stronami podejmowane przez prymasa wskazują, że rozumiał znaczenie funkcji najważniejszego z senatorów. Przy tym trzeba podkreślić, że autorytet posiadał zarówno wśród regalistów jak i rokoszan. Ci ostatni pisali do kardynała tuż przed sejmem w 1607 r. o wspólnym celu -

52 A. Strzelecki, Sejm $z$ r. 1605, Kraków 1921, s. 34.

53 W. Sobieski, op. cit., s. 13.

54 J. Dzięgielewski, J. Maciszewski, op. cit., s. 51. 
naprawie Rzeczypospolitej: „Do czego, iż różne różnym środki się podobają próżno się dziwić, byleśmy jedno wszystcy jeden cel mieli, choc różnemi drogami, da Pan Bóg, do niego przy jść będziem mogli" ${ }^{55}$. Bernard Maciejowski potrafił w taki sposób wesprzeć majestat królewski, że opozycja nie miała do niego większych pretensji.

55 Akta..., t. I, cz. 1, s. 358. 